\title{
THE WELFARE STATE AND THE
} MARKET ECONOMY: THE

\section{AMERICAN AND GERMAN EXPERIENCES OF SOCIAL POLICY}

\author{
Reza Fazeli* Rafat Fazeli ${ }^{\dagger}$
}

Keywords: the United States, Germany, Welfare State, Social Wage, Net Social Wage, Social Policy, Economic Growth JEL: I31, P36

\begin{abstract}
This paper reviews the recent development of the welfare state and social policy in the United States and Germany. The empirical study is primarily based on the comparative study of the trends of the "social wage" and the "net social wage" in the two countries over the last two decades. The paper addresses two major questions. The first question is whether the expansion of social expenditures has posed any drag on capital accumulation and economic growth in these two countries. The second question is whether the increasing ideological challenges from the right and the competitive pressures of globalization have led to retrenchment of the American and German welfare states in the recent decades.
\end{abstract}

*New School for Social Research Address: 7711 East Margaret Dr Anaheim, CA 92808 U.S.A

†University of Redlands Address: 7711 East Margaret Dr Anaheim, CA 92808 U.S.A

Reza Fazeli, Rafat Fazeli - THE WELFARE STATE AND THE MARKET ECONOMY: THE AMERICAN AND GERMAN EXPERIENCES OF 


\section{INTRODUCTION}

The welfare state acquired a broad acceptance as a major socioeconomic achievement of the liberal democracy in the Western industrialized countries during the postwar boom period. The modern and modified vision of capitalist democracy offered, on the one hand, the possibility of high growth rate and, on the other hand, the possibility of continued progression of a comprehensive system of social support for a wider population. In the postwar boom decades, the expansion of social and welfare expenditures faced little challenge, since these redistributionary expenditures could be financed by a rising economic surplus and the wages of a growing number of employed workers.

With the economic crisis the 1970s, the economic growth which made state expenditures relatively cost free and painless was eroded. In fact it was the very legitimacy of the welfare state that came under attack. For over twenty years after the World War II, the Western capitalist nations were successful in generating rapid and sustained growth with high employment through Keynesian economic policies. The "golden age of capitalism" did not endure through the big economic shocks of the 1970s (See Marglin and Schor, 1992). The subsequent decades brought about a growing perception that the generous western welfare states were unsustainable and perhaps even counterproductive.

The welfare state has been subject to rather sharp criticism from its early days and its earlier form when the "Elizabethan Poor law" of 1601 was introduced in England. The critics worried that excessive public spending would erode individual morality and impede economic growth. Thus, the theme is nothing new. But in spite of the continued challenge to the poor relief in the earlier centuries and the Twentieth Century's modern welfare state, social programs rapidly grew in all advanced industrial countries (albeit in various degrees), particularly in the Post-war period. The oil crises of the 1970s changed the prevailing socioeconomic doctrine and the post-war capital-labor accord and more vocal voices were raised against public spending in general, and public social spending in particular.

The views expressed by the New Right in the late 1970s and 1980s acquired more 
acceptances among a larger number of the mainstream economists (Atkinson, 1999). An increasing number of economists joined the Right, blaming transfer programs for their contribution to the decline in economic performance. These economists claim that the increasing size of the public expenditures induces economic inefficiency and undermines growth. They also maintain that welfare expenditures often lead to budget deficits and mounting public debts (Atkinson, 1999:2).

This study will address two major questions (or debates) on the expansion of social programs in the advanced capitalist countries. The first question is whether the expansion of social welfare expenditures would have any major adverse effect on capital accumulation and economic growth. This study will examine the net benefit/ burden position of the working population with respect to state expenditures and taxes in the postwar period. The working population receives benefits in cash and in kind from state expenditures and pays taxes. The "net social wage" is the difference between benefits received and the taxes paid by the whole population of the working class. The examination of the recent trends of "net social wage" will allow us to determine whether the working population has paid in full or in most part for the benefits it has received from social services provided by the state or it has been, indeed, a net recipient of net social wage. The argument that social policy is inherently a drag on capital accumulation and growth may hold if the latter is true and if the net social wage has absorbed a growing portion of stockticker GDP over time.

The second question is whether the economic downturn of the 1970s and increasing conservative criticism of the welfare policies has led to a retrenchment of the welfare state in the recent decades in the advanced capitalist countries. Retrenchment of the welfare state pertains to various cost containment efforts governments have tried to introduce. Retrenchment may take different forms in different countries. It can include cuts in more generous welfare programs and increasing qualification conditions to make benefits less universal and restrict the number of recipients through mean tested programs. .In general retrenchment may involve rolling-back, restructuring, reforming, and even dismantling the welfare state. 
The evidence provided in this study on the recent trends of social wage and net social wage will be used to determine whether the conservative attack on social and welfare programs has led to any major welfare state retrenchment in the two countries of our study. We will see that, in spite of the challenge of the new right to the welfare state and the rule of the one of the most (radically) conservative administrations, in the United States (and the United Kingdom), the net social wage ratio (the share of net social wage in stockticker GDP has remained relatively stable in the recent decades.

\section{VARIETIES OF CAPITALISM AND MATCH- ING FORMS THE WELFARE STATE}

While the Western advanced industrial countries share a general common background in terms of the development of the welfare state, they have been distinct in the scope and the extent of the social programs that they have offered to the population. Historically, in the United States, the practice of democratic policy has been much less egalitarian than Western Europe, particularly the European "social market economies." Compared to Europe, the United States from her early history has followed a vision of capitalism that has been more (than Europe) based on the principle of free enterprise economy. Nowhere in the world, has what Pontusson (2005) calls market-liberal view been as dominant among main stream economists and in public policy as in America. This view promotes the idea of trade-off between equality and growth. Thus what the welfare state is expected to achieve, a higher level of equality, redistribution, and social protection, goes against the ideals of economic efficiency, growth, and employment. For example, Okun (1975) calls the relationship between equality and efficiency "the big trade-off." However, he supports the notion of equal opportunity in a market economy. He argues that inequality of opportunity leads to misallocation of talents, while inequality of rewards brings about more market efficiency by promoting individual incentives to invest, to work hard, and to innovate.

In spite of common background, these countries have, however, been distinct

Reza Fazeli, Rafat Fazeli - THE WELFARE STATE AND THE MARKET ECONOMY: THE AMERICAN AND GERMAN EXPERIENCES OF 
in the scope and the extent of the social programs that they have offered to the population. The recent literature offers a typology of welfare states, based on the recognition of the existence of distinctive varieties of capitalism in the contemporary world. We may then classify the advanced capitalist countries into a limited number of groups, each following a particular model of the interaction between the state and the market economy.

In Gosta Esping-Andersen's well-known classification of the welfare states, the more market oriented countries such as the United States and the United Kingdom are identified as "liberal" in contrast with more progressive "social democratic" states (Esping-Andersen, 1990). In David Soskice's more recent classification the first group are considered as "liberal market economies" in distinction with "coordinated market economies" of Europe which offer more advanced and generous social programs for the working population (Soskice, 1999). This classification focuses on the capacity of states, corporations, and labor unions to coordinate their behavior.

In a recent study, Pontusson (2005), the grouping of the OECD countries is based on a general distinction between two major groups of countries, "social market economies" (SMEs) and "liberal market economies" (LMEs). In this typology, the Anglo-Saxon countries of the United States, the United Kingdom, Canada, Australia, Ireland, and New Zeeland are identified as liberal market economies. The LMEs are distinguished by their lower density of the business communities. In these economies, market transactions rather than corporate coordination, largely define relations among firms as well as relations between the business sector and workers. A second feature of these economies is their weaker unions and less institutionalized collective bargaining system. A third distinction between LMEs and SMEs is their more limited public provision of social welfare and employment protection. In the following section, we will provide an analysis of the empirical evidence for the two countries: 


\section{THE UNITED STATES}

In the United States, the share of both state expenditures and social wage in GDP (the working population's benefit from state expenditures), have remained stable during the period of our study, 1990-2006. This means that generally speaking, the rise of state general and social expenditures have been in line with the trend of GDP and have not led to any additional burden on the economy. (See Figure 1)

For most of this period, there was a positive, but insignificant net social wage. (See Figure 3) This net social wage, however, disappeared and tuned into a little negative value, mostly during the second term of the Clinton Administration. As it appears, the efforts of the Clinton Administration to bring down the budget deficit have influenced this trend. Figure 2 shows that during this short period, the share of social wage in GDP declined, while the labor tax share in GDP increased to the extent that a slightly positive net social wage turned into a slightly negative net social wage. In fact, Figure 4 shows that a rather significant budget deficit of the earlier years (6 percent of GDP in 1992) was reversed into a budget surplus in 1998 and reached the 2 percent of GDP in 2000. This was unprecedented in the recent decades. The United States had not seen a budget surplus for years. But it was during the Reagan Administration that the budget deficit increased to an unprecedented amount and the public debt started to accumulate to a large extent, in most part as a result of the Reagan era supply-side economic policy (or "voodoo economic policy" as President George Bush called it in April 1980 during his presidential campaign against President Ronald Reagan for winning the candidacy of the Republican Party).

Immediately after the inauguration of President George W. Bush, the recent trend of rising budget surplus started to reverse. The modest budget surplus of the Clinton era, turned into a rising budget deficit from 2001 and reached 5 percent of the GDP in 2003. (See Figure 4) As it appears, once again the supply side economic policy played a major role in this process. The Reagan Administration sought a policy of substantial tax cut accompanied with rising public expenditures, particularly military expenditures to win the cold war. 
During his first term (2001-2004), President George W. Bush sought and obtained Congressional approval for a series of tax cuts: the Economic Growth and Tax Relief Reconciliation Act of 2001, the Job Creation and Worker Assistance Act of 2002, and the Job and Growth Tax Relief Reconciliation Act of 2003.

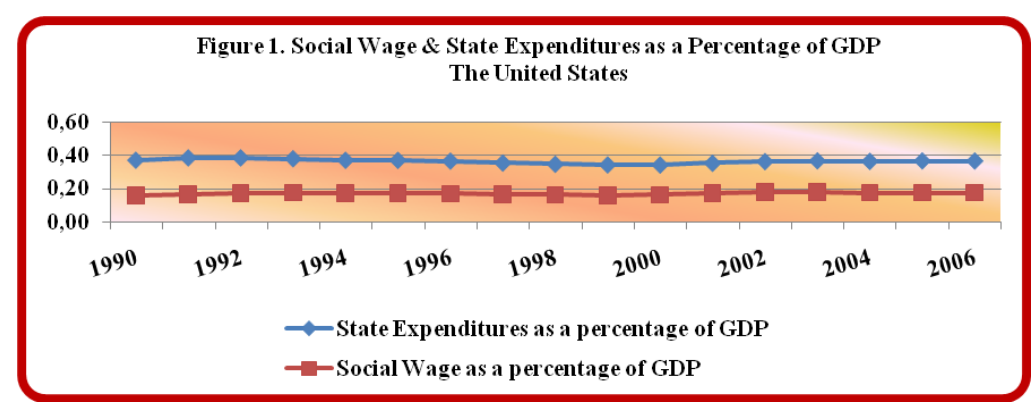

Sources: OECD (2008a), OECD (2008b), and The United States National Income and Product Accounts (NIPA). Various Years. Bureau of Economic Analysis (BEA), http://www.bea.gov/national/nipaweb/index.asp

The new acts included reduced general and capital gains tax rates, increased child tax credit, and the elimination of the so-called "marriage penalty", and were to be expired in 2011 if not renewed. Once again, the policy of tax cut was accompanied by a rising trend in military expenditure, this time for actual wars in Iraq and Afghanistan. Joseph Stiglitz has estimated the total cost of the Iraq War at about $\$ 3$ trillion (Stiglitz and Bilmes 2008) Thus the U.S. public debt grew considerably both in absolute numbers and as a percentage of the GDP, by close to 70 percent from 5.7 trillion in 2001 to close to 10 trillion dollars in 2008. (See Office of Management and Budget 2010: Table 7.1) 


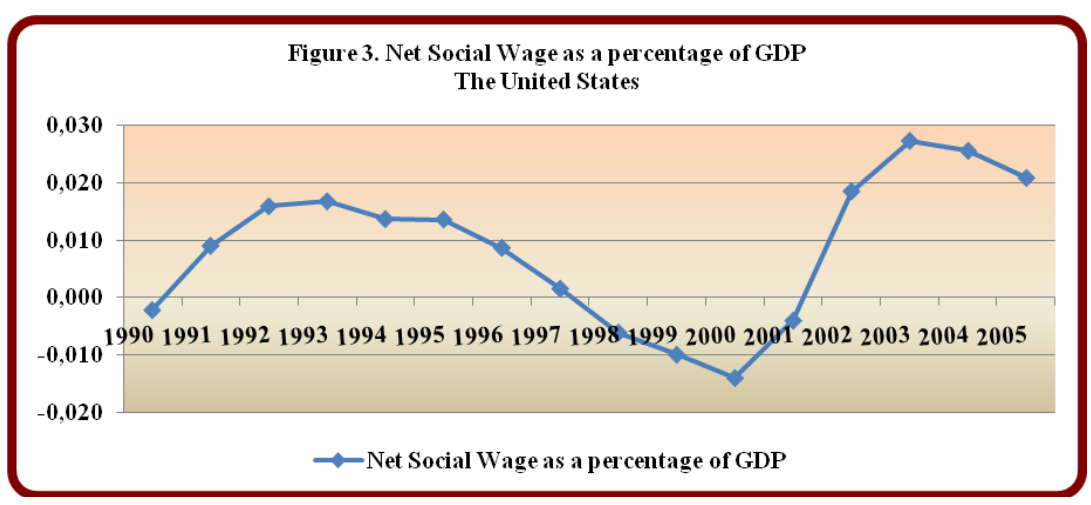

Sources: OECD (2008a), OECD (2008b), and The United States National Income and Product Accounts (NIPA). Various Years. Bureau of Economic Analysis (BEA), http://www.bea.gov/national/nipaweb/index.asp

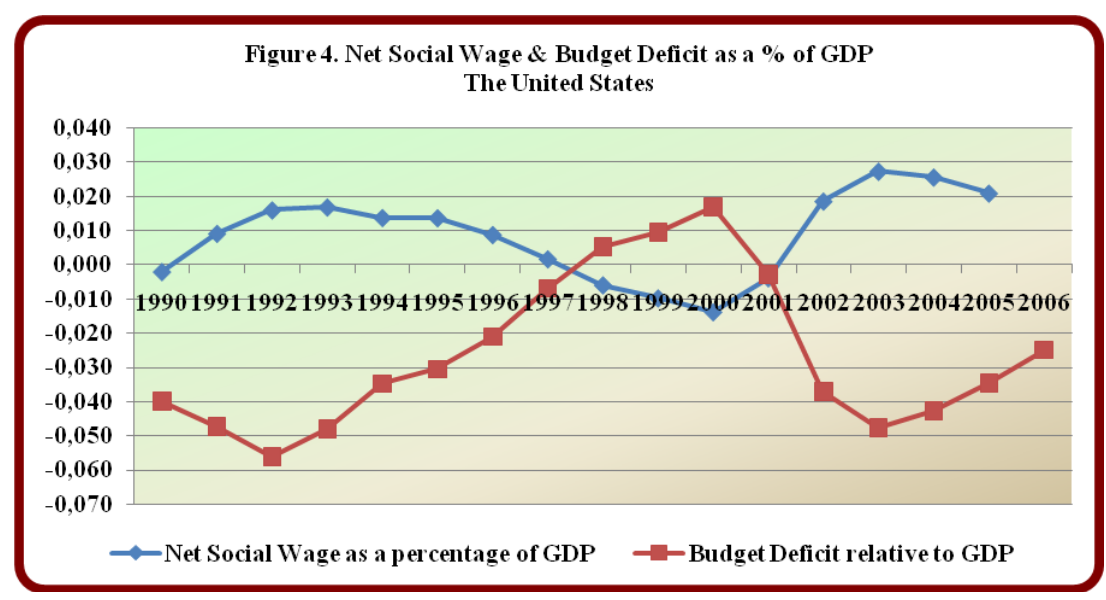

Sources: OECD (2008a), OECD (2008b), and The United States National Income and Product Accounts (NIPA). Various Years. Bureau of Economic Analysis (BEA), http://www.bea.gov/national/nipaweb/index.asp

Social wage as a percentage of GDP started to rise from 2000, in most part, in response to an economic downturn leading to a change in the unemployment

Reza Fazeli, Rafat Fazeli - THE WELFARE STATE AND THE MARKET ECONOMY: THE AMERICAN AND GERMAN EXPERIENCES OF 
rate from 4 percent in 2000 to 6 percent in 2003. Even though the Bush Administration tax cut was more beneficial to capital and the higher income families, the share of the working population in the overall taxes declined. Thus the share of net social wage in GDP increased from a negative 1 percent in 2000 to a positive 3 percent in 2003 and 2004. One important conclusion that we may derive from the above data analysis is that the net social wage has remained relatively stable in spite of its short-term fluctuations. The early 2000s recession happened in spite of a decline in the net social wage. Thus a social wage increase could not be responsible for economic recession. On the contrary, the changes in the net social wage have been in response to changes in the unemployment rate. Figure 5 clearly indicates this point.

As Figure 5 shows, there has been a remarkable correlation between the variations in unemployment rate and the ups and downs of the net social wage ratio. Thus from this perspective, the decline of the net social wage as a percentage of GDP during the second term of the Clinton Administration has not been necessarily due to its restrictive fiscal policy, but as a result of the lower unemployment rate and less demand on unemployment benefits and welfare programs. The Clinton Administration did make the receipt of public assistance more difficult through its "Workfare" form of social welfare program requiring able-bodied adults to work.

President Clinton's proposal included a welfare-payment cutoff after two years, coupled with a bold program of job training and skill upgrading. The final bill, passed in 1996, replaced the existing 60-year-old program. Most recipients were required to work within two years of receiving benefits and were, in principle, limited to a lifetime maximum of five years on welfare rolls. But, as far as the cost is concerned, it does not seem that this program had a significant impact on the level of social spending.

On the other hand, the higher cost of net social wage during the first term of the Bush Administration was not due to its "compassionate conservative" programs, but the recession of the early 1990s and associated higher unemployment rate (from 4 percent in 2000 to 6 percent in 2004). Thus on a closer review we find out that in reality, the overall effect of social policy has been remarkably stable 
in the entire period.

As we noted earlier and as reflected in Figure 4, there has also been a close association between the trends of net social wage and budget deficit. We may, therefore, conclude that higher unemployment rates (in part as a result of recessionary pressures) have led to higher public expenditures in general and social expenditures in particular. Higher level of public expenditures have been required, in part in response to higher level of unemployment requiring the provision of more unemployment benefits and higher level of welfare benefits (public assistance), and in part in response to the declining economy in the form of discretionary government expenditures or tax cuts. These policy responses would often lead to higher level of budget deficit as a share of GDP.

In the United States, the variations of budget deficit as a share of GDP are in most years consistent with the variations of the net social wage ratio. It rises when net social wage ratio rises and declines when net social wage ratio declines. (See Figure 4) This does not mean that the increase in net social wage is responsible for a higher budget deficit. As it appears, the ups and downs of both net social wage and budget deficit occur in response to the macroeconomic conditions. This becomes evident when we look at Figures 5 demonstrating the variations of net social wage ratios and unemployment rates over this period.

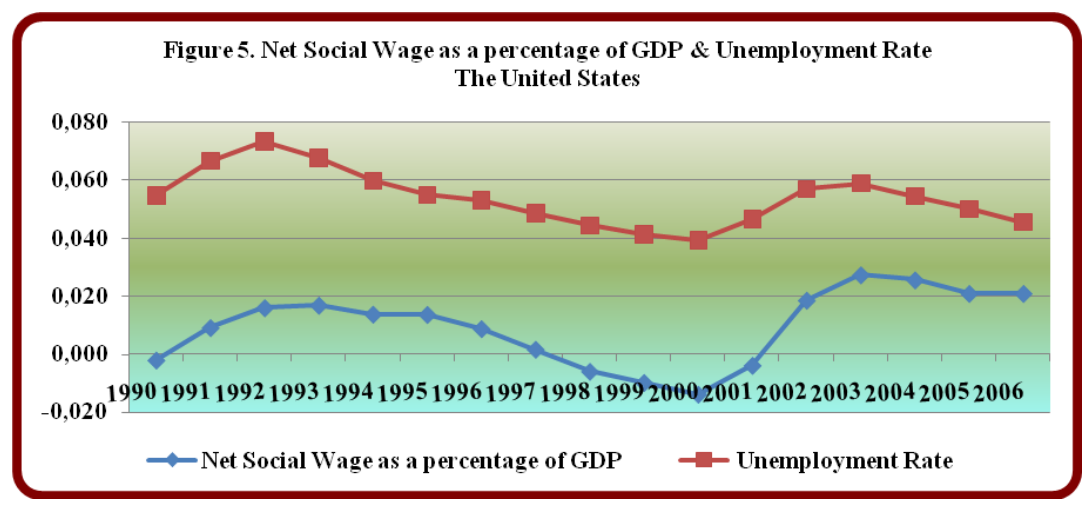

Sources: OECD (2008a), OECD (2008b), and The United States National Income and Product Accounts (NIPA). Various Years. Bureau of Economic Analysis (BEA), http://www.bea.gov/national/nipaweb/index.asp 
Finally, Figure 6 shows that net social wage per worker has remained quite stable over time, while GDP per worker or labor productivity has continuously increased at a stable rate. GDP per worker has increased from about $\$ 47000$ in 1990 to around $\$ 89500$ in 2006 . In the same period, net social wage per worker has increased from $-\$ 100$ to $\$ 1870$. This is an increase of about $\$ 2000$, while GDP per worker has increased by $\$ 42,500$. Thus the increase in the cost of net social wage comes to be less than 5 percent of the productivity increase. We can, therefore, conclude that the increase in the net social wage has not been any drag on economic growth.

As we indicated, both social wage and net social gage have remained rather stable relative to GDP, changing only in response to changing macroeconomic conditions and unemployment rate. However, the social policy has fallen far short in compensating for the growing inequality and increasing poverty rate in the last three decades. While Public services such as education and health have been distributed more equally than income, their scale has not been sufficient to overcome the increasing inequality in income and wealth.

As Schiller (2008) states, Americans are becoming more and more convinced that 'America is becoming a nation of 'Haves' and 'Have-nots.' Public opinion polls reveal that 60-70 percent of the population perceives that the 'rich are getting richer' while the 'poor are getting poorer.' These perceptions of wide and increasing inequality add intensity to political debates about tax reform ('tax cuts for the rich'), poverty policy, and income support for the middle class (relieving the 'middle class squeeze')."

This public sentiment is supported by the data from the annual Census surveys. The data points to rather drastic increasing inequality in the recent decades. In 2006 , the lowest quintile got only 3.4 percent of America's total income while the highest quintile got a huge 50.5 percent of the total. This means that the piece of the pie received by the "rich" (the top quintile) is 15 times larger than the slice received by the "poor" (the bottom quintile). Moreover, as the data shows that the split between the "Haves" and the "Have-nots" has been growing over time: 
Economic Research - Ekonomska Istrazivanja Vol. 25, SE 1, 2012

TABLE 1 - Income Shares

\begin{tabular}{ccc}
\hline \hline Year & Top Quintile & Bottom Quintile \\
\hline $\mathbf{1 9 7 0}$ & 43.3 & 4.1 \\
$\mathbf{1 9 8 0}$ & 44.1 & 4.2 \\
$\mathbf{1 9 9 0}$ & 46.5 & 3.8 \\
$\mathbf{2 0 0 0}$ & 49.4 & 3.6 \\
$\mathbf{2 0 0 6}$ & 50.5 & 3.4 \\
\hline \hline
\end{tabular}

Source: U.S. Annual Census, data drawn from Schiller 2008

This is not to say that the poor has become poorer in absolute numbers. GDP in 1980 was $\$ 6.3$ trillion in 2006 prices. Thus in 1980, the share of the poor was $\$ 265$ billion (4.2\% of $\$ 6.3$ trillion) and it increased to $\$ 476$ billion in 2006 (3.4\% of $\$ 14$ trillion, the 2006 GDP). This is a substantial increase in the standard of living of the poor. Allowing for population growth still the average "poor" household received 40 percent more income in 2006 than in 1980. The point is, however, that the rich has received a much higher proportion of the benefits of economic growth than any other income group in the society.

In fact, the median household income has declined in dollar term in recent years. The median income has declined from $\$ 49,244$ in 1999 to $\$ 48,201$ in 2006 . The data suggests that the middle-class gained relatively little from the growth of the economy since 1986 and nothing at all since 1999. Thus the data supports the notion of a "struggling middle class." (Schiller, 2008)

Not only the rich has become richer, the very rich have gained even more relative to the rest of population. In 2005, Income inequality grew significantly: the top 1 percent of Americans, those whose incomes exceeded $\$ 348,000$ received their largest share of national income since 1928. The top 10 percent, roughly those earning more than $\$ 100,000$, also received a level of income share unprecedented

Reza Fazeli, Rafat Fazeli - THE WELFARE STATE AND THE MARKET ECONOMY: THE AMERICAN AND GERMAN EXPERIENCES OF 
since 1928, just before the Depression. In 2005, total income in the United States increased by 9 percent; but the top 10 percent pocketed the entire gain. In fact the gain, in most part, went to the top 1 percent, whose incomes rose to an average of more than $\$ 1.1$ million each, an increase of more than $\$ 139,000$, or about 14 percent. The average incomes of the households in bottom 90 percent dropped by 0.6 percent compared to the previous year. (Johnston, 2007)

The new data also shows that by 2005, the top 300,000 of the population collectively enjoyed almost as much income as the bottom 150 million. The average income of the top 1 percent reached 440 times of the average income of those in the bottom half of the population. This gap is the double of what it was in 1980. The top 10 percent of Americans collected 48.5 percent of all reported income in 2005, 33 percent higher than the late 1970s and the highest since 1928 in which this ratio was 49.3 percent. (Johnston, 2007)

The United States has one of the highest poverty levels among the world advanced industrial economies. Steensland (2007) considers the American struggle in addressing the issues of fairness and poverty as "the Failed Welfare Revolution," showing that things could have turned out differently if policymakers had succeeded to establish, as intended, a program guaranteeing a basic economic security for all workers. He argues that, in fact, the program of guaranteed basic income had received broad bipartisan support. Such a welfare reform proposal was tried during 1960s as President Nixon's Family Assistance Plan (FAP) and later in the 1970s, as the Carter administration's Program for Better Jobs and Income (PBJI). Steenlands has explored why such an unlikely policy idea first developed to the factors that sealed its fate and how the failure of these efforts deprived America from the opportunity to address the chronic condition of poverty.

Steensland argues that the most challenging obstacle to guaranteed income plan was cultural, demanding American's longstanding distinction between "deserving" and "undeserving" be recognized in the adoption of new policy. This episode, as Steensland points out, "has largely vanished from America's collective memory." The question is whether the passage of a basic income scheme would have mitigated the rise of conservative welfare retrenchment in the 1980s. 
Caputo (2009) argues that the passage of guaranteed income would not prevent the conservative attack on the welfare state: "the rise of the conservative ideology as a dominant force in US politics from the 1980s onward went well beyond debates about the welfare program then known as Aid to Families with Dependent Children (AFDC) which a the focus of the Nixon administration's Family Assistance Plan (FAP) and the Carter administration's Program for Better Jobs and Income (PBJI)." He points out that the shift in the political perspective was mainly in response to the oil crisis of 1973 and "welfare reform per se played a minor role in the totality of the Carter administration and was virtually ignored during the first term of the Reagan administration."

With regard to the cultural argument, Caputo (2009) believes that "Steensland makes a perhaps too strong case that retention of the moral categories deserving vs. undeserving operated as a more or less cognitive straitjacket precluding passage of FAP as well as the Program for Better Jobs and Income (PBJI)." He has doubts that this moral dichotomy might have been overcome and opened a way for the new path. He further argues that race has also been an integral part of this story: "... the prospect of poor Southern blacks receiving income from FAP at levels well above their earned wages directly threatened the white economic and political basis of the US South and galvanized opposition from Congressional Southern Democrats. Racial composition of families receiving benefits were the most decisive of all explanations: the more blacks on the rolls, the tougher the state policies."

In spite of its shortcomings, Brian Steenland's analysis points to a real lost possibility during 1960s and 1970s. The attention to the prospects of the so called "deserving poor" would have definitely brought a strong political argument in supporting the guaranteed income policy. Moreover it might address one of the shortcomings of the U.S. welfare policy, promoting the poor not to sick employment in order to remain qualified for medicate. It is difficult to know at this time whether this effort would have been sufficient for the supporters of this policy to win in the legislative process. The recent struggle for passing the medical insurance bill shows that the dynamics of such legislative processes cannot be entirely predicted in advance. 


\section{GERMANY}

Both state expenditures and social wage have remained quite stable relative to gdp (See Figure 1.) Figure 2. shows that social wage and the taxes paid by labor have increased between 1990 and 2006 in a relatively slow rate-somewhat faster between 1990 and 1996 and slower afterwards. The initial faster increase can be attributed mainly to the increasing costs of reunification. The rate of unemployment increased from 7 percent in 1990 to close to 13 percent in 1997. The jump in unemployment rate was more drastic in the East than the West. It almost doubled in the East from about 10 percent in 1990 up to about 20 percent in 1997 (see Ebbinghaus and Eichhorst, 2006). The gap between social wage and labor taxes has increased in the more recent years (Figure 2). This figure shows that social wage and labor taxes relative to GDP have both increased with the same rate between 1990 and 1996 (social wage ratio from 28 percent to 33 percent and labor tax ratio 23 percent to 26 percent), implying that the net social wage has remained stable over this period. Social wage ratio has declined to 32 percent and settled at this level for the remaining years, going up slightly to 33 percent in 2002 and declining slightly to 31 percent. Labor tax ratio, has stayed at its 1996 level of 26 percent for four years, declining to 25 percent in 2000, declining to 24 percent in 2004 after remaining constant for a few years, and declining again to 23 percent in 2006. This means that labor tax ratio has come back to the same 23 percent that it was in 1990, while social wage ratio has increased from 28 percent to 31 percent.

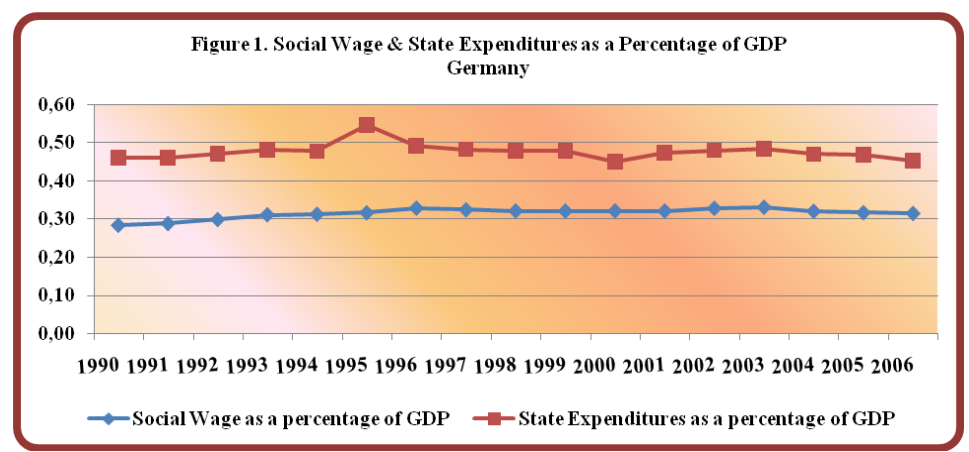

Reza Fazeli, Rafat Fazeli - THE WELFARE STATE AND THE MARKET ECONOMY: THE AMERICAN AND GERMAN EXPERIENCES OF SOCIAL POLICY 
Economic Research - Ekonomska Istrazivanja Vol. 25, SE 1, 2012 Page:178

Sources: OECD. (2008a), OECD (2008b), Statistisches Bundesmat Deutschland.2010. http://www.destatis.de/jetspeed/portal/cms/Sites/destatis /Internet/ EN $/$ press $/$ pr/2010/01/PE10__012__811,templateId=renderPrint.psml and Eurostat.

2008. "National Accounts," http://epp.eurostat.ec.europa.eu/portal/page/portal/ national_accounts/data/main_tables

Figure 2. Social Wage \& Lab or Taxes as a \% of GDP Germany

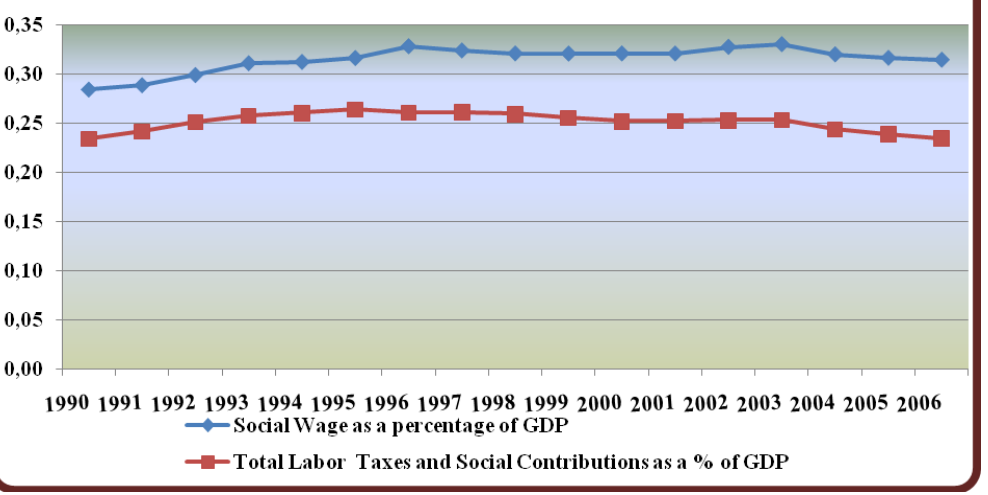

Sources: OECD. (2008a), OECD (2008b), Statistisches Bundesmat Deutschland.2010. http://www.destatis.de/jetspeed/portal/cms/Sites/destatis/Internet $/ E N /$ press $/$ pr

/2010/01/PE10__012__811,templateId=renderPrint.psml and Eurostat. 2008.

"National Accounts" http://epp.eurostat.ec.europa. eu /portal/page/portal/ national_accounts/data/main_tables

Thus the gap between social wage ratio and labor tax ratio (or net social wage ratio) has increased from 5 percent in 1990 to 8 percent in 2006 (see also Figure 3 for the trend of the net social wage ratio). 


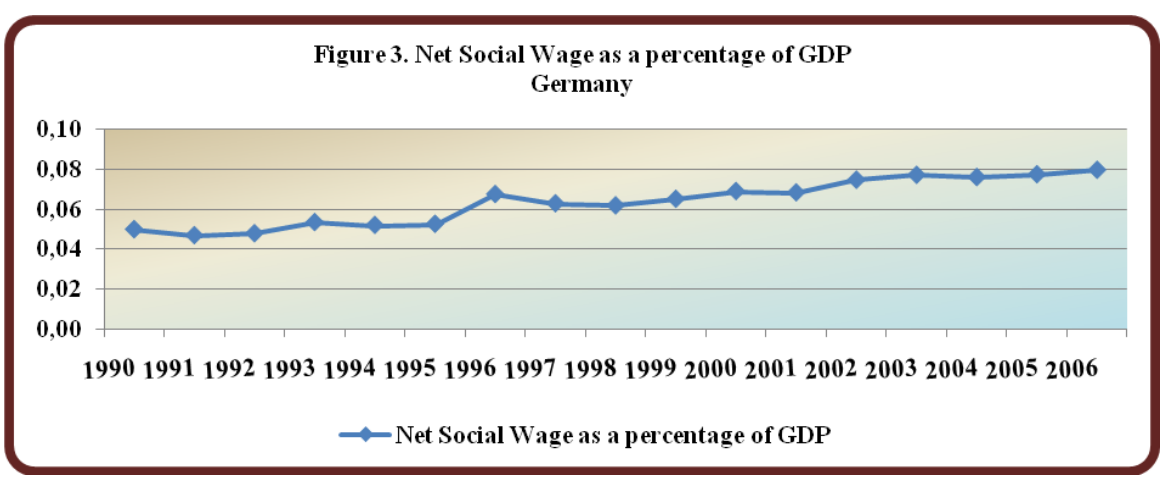

Sources: OECD. (2008a), OECD (2008b), Statistisches Bundesmat Deutschland.2010. http://www.destatis.de/jetspeed/portal/cms/Sites/destatis/Internet/EN/press/pr

/2010/01/PE10__012__811,templateId=renderPrint.psml and Eurostat. 2008. "National Accounts" http://epp.eurostat.ec.europa .eu/portal/page/portal

/national_accounts/data/main_tables

However, the increase in social expenditures ratio from 1990 to 2006 of 4 percent appears to be entirely due to the increase of the social protection from 18 percent to 22 percent over the same period. And the rise of social protection relative to GDP seems to be the result of an increase in the rate of unemployment from 5 percent in 1990 to 10 percent in 2006. We should add that both social protection ratio and unemployment rate have been relatively stable from 1996 to 2006, the first one reaching 22 percent in 1996 and the latter reaching 9 percent in the same year.

Reza Fazeli, Rafat Fazeli - THE WELFARE STATE AND THE MARKET ECONOMY: THE AMERICAN AND GERMAN EXPERIENCES OF 


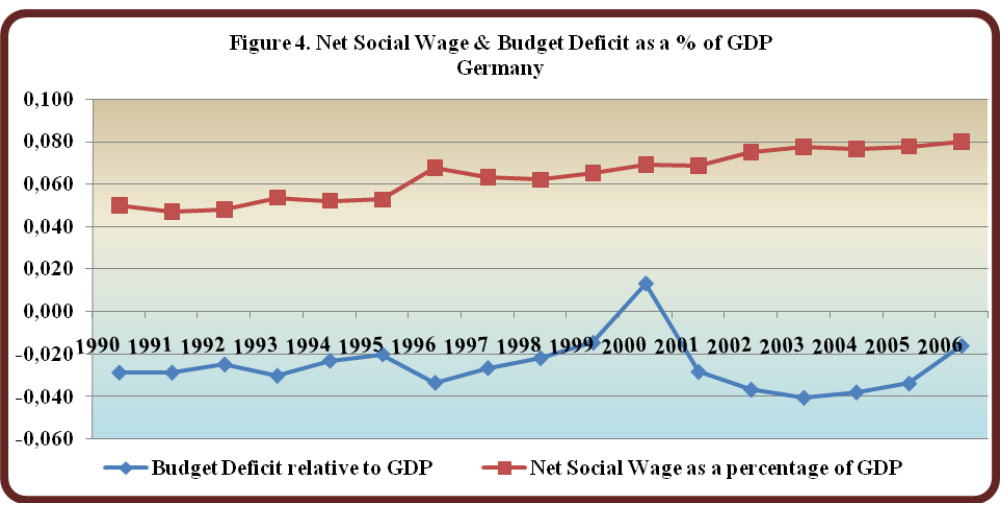

Sources: OECD. (2008a), OECD (2008b), Statistisches Bundesmat Deutschland.2010. http://www.destatis.de/jetspeed/portal/cms/Sites/destatis /Internet/ EN/press/pr/2010/01/PE10__012__811, templateId=renderPrint.psml and Eurostat. 2008. "National Accounts"

As Figure 4 shows, there is a relative match between the trends of the net social wage and budget deficit relative to GDP. While net social ratio has been increasing at a slow rate, the budget deficit relative to GDP has remained almost unchanged, except after 2001 that it has increased modestly up to 4 percent of GDP in 2003 and has gradually declined to its usual trend of around 2 percent. The recent Finance Ministry announcement has forecasted a 2010 budget deficit of 5.5 percent of GDP. In 2009, the budget deficit was 105 billion Euros or 4 percent of GDP, which was 2.620 trillion Euros, 5 percent lower than 2008. The 2009 GDP decline was larger than any year since 1945 (Statistisches Bundesmat Deutschland, 2010) What is responsible for this hike in budget deficit at this time is primarily the stimulus package in response to the current economic crisis. Just recently, Chancellor Angela Merkel announced a 50 billion Euros package, the largest since 1945. In addition, the plan includes a 100-billion-euro loan guarantee to help suffering companies hurt by the credit crunch (Ebusiness, 2010). On top of these, the bail-out of the Greek economy, staggered by huge 
debt will cost the Germans dearly. The German government may end up helping Spain and Portugal if they end up running into a similar financial crisis.

As Figure 5 displays, over the period of our study, 1990-2006, there has been an overall association between the net social wage ratio and the rate of unemployment, even though their variations do not necessarily match in the shorter periods. The rate of unemployment started from 5 percent in 1990, increasing to 8 percent in 1994, staying at 8 percent or higher for the remaining years. In 2006, the unemployment rate was 10 percent. The share of net social wage in GDP was 5 percent in 1990, growing to 8 percent in 2003 and staying at that level up to the last year of our study, 2006. As a matter of fact, unemployment rate has been lower in the recent years than 2003-2006 period, in spite of the recent vicious economic downturn. The highest was 8.2 percent in April 2009 due to severe financial problems (IMF, 2009). Thus, the moderate rise in the net social wage ratio (net social wage as a percentage of GDP) in the recent years has been, in the most part, in response to the higher unemployment rate rather than a more egalitarian social policy. The association between unemployment rate and net social wage ratio has not been as strong as the United States. In other worlds, the social welfare policy in the German social market economy has been more independent from the economic constraints than in American liberal market economy. However, both German and American welfare states have been resilient (without being overly ambitious in their programs) in spite of the increasing criticism from the right to the Western generous welfare policies.

Reza Fazeli, Rafat Fazeli - THE WELFARE STATE AND THE MARKET ECONOMY: THE AMERICAN AND GERMAN EXPERIENCES OF 


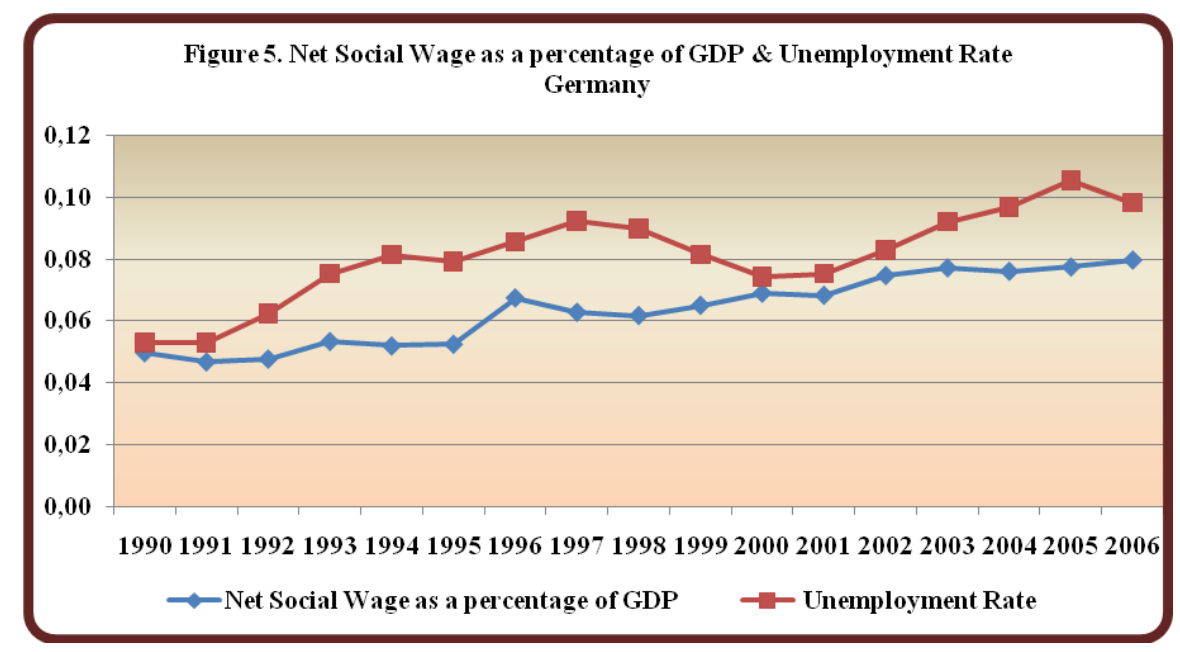

Sources: OECD. (2008a), OECD (2008b), Statistisches Bundesmat Deutschland.2010. http://www.destatis.de/jetspeed/portal/cms/Sites/destatis/Internet/ EN $/$ press $/$ pr $/ 2010 / 01 /$ PE10__012__811,templateId=renderPrint.psml and Eurostat. 2008. "National Accounts

\section{CONCLUDING REMARKS}

Our study is concerned with the impact of the state social policy on the working population as a whole. This study provides a basis to evaluate whether the working population has received a net benefit (benefit minus taxes) for the overall state expenditures. It does not, however, address the income redistribution among different income brackets. Pontusson (2005: Table 3.2) provides a picture of variation in the level of income inequality among OECD countries as well as its change from the early 1980s to the 1990s. The analysis of this evidence leads to two major implications (Luxemburg Income Study, 2004). The Gini Coefficient has increased in all OECD countries except in the Netherlands and Ireland in which it has slightly declined. But no country has experienced such a high Gini Coefficient as the United States. In terms of rising inequality, 
the United States is ranked second to the United Kingdom. The US Gini Coefficient has increased from 40.8 in 1997 to 47 in 2006. The German Gini coefficient has declined from 30 in 1994 to 27 in 2006 (CIA Factbook, 2010). As noted by Gottschalk and Smeeding (1997) and recently by Brandolini and Smeeding (2008) among others, wage and income inequalities have been on the rise across Western nations, particularly in the leading "liberal market economies" of the United States and the United Kingdom.

Pontusson also asserts that "the main tenets of the market-liberal discoursethat the institutional arrangements for more equal distribution of income and consumption lead to slower growth and economic efficiency-are questionable, if not refutable." (Agartan, 2008). He rejects the myth that the extensive social and welfare programs of the SMEs hinder economic growth, arguing against the supposed trade-off between inequality and economic efficiency, as many American main stream economists have claimed. He disagrees with the conventional outlook that view publicly provided social and welfare services as inefficient, and draws attention to the positive implications of the more egalitarian distributional policies in the SMES. In his view, SMEs have a major advantage to LMEs and that is their high levels of society-led coordination, allowing negotiated policy compromises among the major economic actors. The negotiated solutions between business and labor with the coordination of the government induce growth, while maintaining higher levels of social equality. In support of his arguments, he provides detailed empirical analysis, illustrating that it is not the economic growth but rather job creation that represents a major challenge to the SMES.

Jeffrey Sachs, a leading economist himself, disagrees with the economic orthodoxy of the trade-off between efficiency and equity. He maintains that a generous social-welfare state can be compatible with a strong and vibrant economy. It can generate fairness and economic equality, while maintaining global competitiveness. Sachs argues that the Nordic countries present a prime example of why economic prosperity and social protection need not be antagonistic or mutually exclusive ideals. Instead, the Scandinavian model of Sweden, Denmark, Finland, and shows that it is doable to combine a "healthy respect for 
market forces with a strong commitment to antipoverty programs". The high tax Nordic countries have created dynamic and efficient economies through the allocation of resources to research and development, higher education, and infocomm technology. He also maintains that the Nordic nations have been able to produce a desirable balance between social security and internationally competitive market-based economies. "On average, the Nordic countries outperform the Anglo-Saxon ones on most measures of economic performance. Poverty rates are much lower there, and national income per working-age population is on average higher (Sachs, 2006b).

The German "Soziale Marktwirtschaft ," or "social market economy" has not been as egalitarian as the Nordic social market economies in terms of social and welfare programs, but it has offered a much more generous social protection programs than the "liberal market economies." It tries to combine the virtues of a market system with the virtues of a social welfare system. We should add that the high tax Nordic countries and Germany have maintained a relatively low corporate tax rate. Taxes on corporate income have been only 2.4 percent of GDP in Sweden and 2.9 percent of GDP in Denmark in 2002. These numbers are not that much higher than the same ratio for the United States at 2 percent. The corporate tax has constituted a higher percentage of GDP in other liberal market economies: 2.9 percent in the United Kingdom, 3.4 percent in Canada, and 5.3 percent in Australia. The corporate tax ratios have also been relatively low in the Continental SMEs, the most remarkable of which is the German ratio at only 1 percent of GDP in 2002 and 2003 (CBO, 2005). Thus it is possible to maintain a corporate friendly egalitarian welfare state or as Sachs (2006b) points out a "healthy respect for market forces with a strong commitment to antipoverty programs".

Germany enjoyed its strongest growth spurt in 2010 since the country was reunified two decades ago, just a year after suffering its worst recession since the Second World War. Powered by buoyant exports to the Far East and an upturn in business investment and household spending, the economy grew by $3.6 \%$ last year. "Germany enjoys strongest economic growth since reunification" (Kollewe, 2011). However, German record has been mixed in the last two decades. Her 
growth rate in the recent decades has been close to an average of 2 percent with substantial ups and downs, while the United States has enjoyed an average growth rate of 3.3 percent (European Communities, 2002).

The German growth has not been impressive in the last two decades. The Nordic economies have done substantially better in this regard. German economic policy and industrial strategy worked extremely well for several decades after World War II and those have continued to work well in some regards. One should not lose sight of German miracle of impressive postwar economic recovery and the decades of strong growth, low inflation, and low unemployment. In the mid1970s, German unemployment was less than 2.5 percent, less than half of that of the United States, and its inflation rate was virtually zero. During those years, Germany also experienced a very satisfactory rate of real economic growth that helped her to close the gap between per capita real GDP in Germany and in the United States (Feldstein, 2002).

A possible cause of less satisfactory performance of German economy is the West and East unification of 1990. There is no question that unification shock has been very costly to German economy. Jorg Bibow (2005) has challenged this view, arguing that "Germany's fiscal crisis cannot be attributed to unification per se; it arose as a consequence of ill-guided macroeconomic policies pursued in response to that event." He maintains that the structural problems that appeared in the 1990s were, indeed, symptoms of persistent macroeconomic mismanagement and extended domestic demand stagnation.

Feldstein (2002) identifies another problem in the German path to growth. Germany has lost the independent monetary policy as a member of the European Economic and Monetary Union (EMU). Thus Germany has no control over the rate of interest and the growth of the money supply, which are now determined by the European Central Bank (ECB) rather than the German Bundesbank. Having been in control, the Bundesbank would have probably pursued an aggressive policy of expansionary policy through interest rate reductions and expanding money supply. This policy would have been consistent with German long history of cautious monetary policy devoted to achieving low inflation. This would be consistent, since an inflation rate of only 2.2 percent would not have 
been alarming.

Finally, the trend confirms that the welfare state and social policy have not retreated and have remained remarkably resilient in the two countries, in spite of the conservative challenges of the 1980s and growing main stream consensus, particularly among economists, that the welfare state has a damning effect on growth and prosperity. In the 1990s the much talked about forces of globalization (accompanied by costly demographic changes and attendant political pressures) seemed to threaten the very existence of the social-market economies of Europe. The results of our study, confirm that neither the challenges from the right and nor the forces of globalization have succeeded to dismantle the American and German welfare states. We should, however, indicate that social spending as a share of GDP has stagnated or has been growing at a slower rate than the earlier decades. While the working population has not suffered big losses in terms of the egalitarian social services, it has experienced a major set-back in the labor market induced income distribution, principally in the United States. It is, then, reasonable to say that while the conservative assault on the welfare state and the merit of a more equitable income distribution has not led to the dismantling of the welfare state, it has contributed to a change of institutions and culture that accommodate the growing inequalities of the recent decades in a number of OECD societies.

\section{REFERENCES}

Agartan, K. (2008): Comments on Inequality and Prosperity: Social Europe vs. Liberal America, Capital \&amp; Class, Spring 2008 Atkinson, A. B. (1999): The Economic Consequences of Rolling Back the Welfare State, Cambridge: the MIT Press Bibow, J. 2005. Germany in crisis: the unification challenge, macroeconomic policy shocks and traditions, and EMU, International Review of Applied Economics, Volume 19 Issue 1, January: 29-50 Brandolini, Andrea and Timothy M. Smeeding. (2008): Inequality: International Evidence, the New Palgrave Dictionary of Economics, Second Edition, 


\section{Edited by Steven N. Durlauf and Lawrence E. Blume}

http://darp.lse.ac.uk/papersdb/Brandolini-Smeeding_\%28Palgrave2e\%29.pdf Caputo, R.K. (2009): Commentary on the book, The Failed Welfare Revolution: America's Struggle over Guaranteed Income Policy, Tenth USBIG Congress - New York City, 27 February - 1 March.

CBO. (2005): Corporate Income Tax Rates: International Comparisons, Congress of the United States, Congressional Budget Office, http://www.cbo.gov/ftpdocs/69xx/doc6902/11-28-CorporateTax.pdf CIA. (2010): The World Factbook, https://www.cia.gov/library/publications/theworld-factbook/rankorder/2001rank.html; and also http://www.theodora.com/wfbcurrent/france/france_economy.html

https://www.cia.gov/library/publications/the-world-factbook/

fields/2172.html, and U.S. Census Bureau 2010

Ebbinghaus, Bernhard and Werner Eichhorst (2006): Employment Regulation and Labor Market Policy in Germany, 1991-2005, IZA Discussion Paper No. 2505 December

Ebisiness. (2008): German budget deficit to break EU rules in 2010, 14 January 2009, http://www.eubusiness.com/news-eu/1231921022.85/ Esping Andersen Gøsta (1990): The Three Worlds of Welfare Capitalism, Princeton: Princeton University Press

European Communities. (2002): Germany's growth performance in the 1990's, European Commission, Directorate General for Economic and Financial Affairs,

http://ec.europa.eu/economy_finance/publications/publication1878_en.pdf) Eurostat. 2008. "National Accounts" http://epp.eurostat.ec.europa.eu/portal/page/portal/national_accounts/data/m in_tables

Feldstein, M. (2002): Germany's Economic Ills, http://www.nber.org/feldstein/siebert.html

Gottschalk, Peter and Timothy M. Smeeding. (1997): Cross-National Comparison of Earnings and Income Inequality, Journal of Economic Literature, Vol. 35, No. 2, June, 633-687 
Economic Research - Ekonomska Istrazivanja Vol. 25, SE 1, 2012 Page:188

International Monetary Fund. (2009): 2009 World Economic Outlook, http://www.econstats.com/weo/CUSA.htm

Johnston, David Cay. (2007): The gap between rich and poor grows in the

United States, March, http://www.nytimes.com/2007/03/29/business/worldbusiness/

29ihtincome.4.5075504.html.

Kollewe, J. (2011):Germany enjoys strongest economic growth since reunification, Guardian.co.uk, Wednesday 12 January,

http://www.guardian.co.uk/world/2011/jan/12/germany-enjoys-economic-growthspurt

Marglin, S A. and Juliet B. Schor (1992): The Golden Age of Capitalism:

Reinterpreting the Postwar Experience, Clarendon Press

OECD. (2008a): National Accounts of OECD Countries Volume I, Main Aggregates, Source OECD

(2008b): National Accounts of OECD Countries, Volume IV, General Government Accounts, Source OECD

Office of Management and Budget (2010): Budget of the U.S. Government:

Historical Tables,

http://www.whitehouse.gov/omb/budget/fy2010/assets/hist.pdf

Sachs, J. (2006): Welfare States beyond Ideology, Scientific American

Schiller, Bradley R. (2008): "NEWS FLASH," The Economy Today and

Essentials of Economics texts, March

Soskice, D. (1999): Divergent Production Regimes, in Continuity and

Change in Contemporary Capitalism, ed. Herbert Kitschelt, Peter Lange, Gary Marks, and John Stephens,

Cambridge: Cambridge University Press

Statistisches Bundesmat Deutschland. (2010): Germany experiencing serious recession in 2009 ,

http://www.destatis.de/jetspeed/portal/cms/Sites/destatis/Internet/

$\mathrm{EN} / \mathrm{press} / \mathrm{pr} / 2010 / 01 / \mathrm{PE} 10 \_012 \_$_ 811,templateId=renderPrint.psml

Reza Fazeli, Rafat Fazeli - THE WELFARE STATE AND THE MARKET ECONOMY: THE AMERICAN AND GERMAN EXPERIENCES OF 
Economic Research - Ekonomska Istrazivanja Vol. 25, SE 1, 2012 Page:189

Steensland, B. (2007): The Failed Welfare Revolution: America's struggle, Princeton: Princeton University Press

Stiglitz, Joseph and Bilmes, Linda. (2008): The Three Trillion Dollar War, placeStateNew York: W.W. Norton \& Company

The United States National Income and Product Accounts (NIPA). Various

Years. Bureau of Economic Analysis (BEA),

http://www.bea.gov/national/nipaweb/index.asp

US Census Bureau. (2010): 2010 Census Data, http://2010.census.gov/

2010census/data/

Reza Fazeli, Rafat Fazeli - THE WELFARE STATE AND THE MARKET

ECONOMY: THE AMERICAN AND GERMAN EXPERIENCES OF

SOCIAL POLICY 